\title{
Corrosion Rates of Binary Alloys of Nickel and Iron Measured by Polarization Methods
}

\author{
W. J. Schwerdtfeger \\ Institute for Materials Research, National Bureau of Standards, Washington, D.C.
}

(May 6, 1966)

\begin{abstract}
Specimens of ten binary alloys of nickel and iron containing $3,5,10,16,20,30,36,50,57$, and 81 percent $\mathrm{Ni}$ and of the metals nickel and iron were immersed for 7 months in 265 gallons of city water to which had been added 3 percent by weight of sodium chloride.

Cathodic and anodic polarization curves of the specimens were obtained at about 22 periodic intervals throughout the exposure period. Corrosion currents, calculated from currents at breaks in the curves, were converted to corrosion rates expressed as weight losses by applying Faraday's law. The calculated weight losses were in reasonable agreement with the actual weight losses.

The polarization rates, $\Delta V / \Delta I$, of the specimens calculated from cathodic polarization curves (cathodic control prevailed) at several intervals throughout the exposure period were plotted on logarithmic coordinates with respect to the corrosion current densities calculated from breaks in the same curves. Similarly, the averages of these $\Delta V / \Delta I$ values were also plotted on logarithmic coordinates versus the actual corrosion rates expressed as weight losses. Both plots conformed to the theoretical slope of -1 .
\end{abstract}

Key Words: Corrosion rates, Ni-Fe alloys, polarization techniques, polarization rate, polarization resistance, polarization circuits, $\mathrm{Ni}-\mathrm{Fe}$ pitting.

\section{Introduction}

A few years ago, it was demonstrated experimentally that the corrosion rates of a series of ferrous alloys, containing chromium additions up to 18 percent and a similar series with 3 percent of silicon in addition to the chromium, exposed to a 3 percent sodium chloride solution, could be calculated from currents associated with changes of slope (breaks) in polarization curves [1]. ${ }^{1}$ The sensitivity of the method was shown by the fact that the weight loss of the $18 \mathrm{Cr}$ alloy attributed to corrosion was measured satisfactorily even though the apparent area affected by corrosion was less than 1 percent of the entire surface. The polarization curves of the alloys showed that the known critical change in corrosion rate (expressed as weight loss) for this range of chromium occurred when the corrosion reaction changed from cathodic to anodic control, between 11.4 and 14.3 percent $\mathrm{Cr}$.

The reason for the laboratory measurements described in this paper, using binary alloys of nickel and iron, was to explore further the practicability of polarization techniques as methods of evaluating rates of corrosion. The corrosion rates of several binary alloys between 3 and 81 percent nickel, including the unalloyed metals, were measured by the above technique and also by a method which has been called "polarization resistance" but is referred to by this writer as polarization rate $\Delta V / \Delta I$.

'Figures in brackets indicate the literature references at the end of this paper.
The significance of the slope, $\Delta V \mid \Delta I$, of the controlling polarization curve was observed by the author and related to the break method [2] but was never further pursued until after Skold and Larson [3] found the method favorable. They observed that a linear relationship existed when corrosion rate (expressed as weight loss) was plotted versus $\Delta V / \Delta I$ on logarithmic coordinates. Shortly thereafter, Stern provided a theoretical basis for the polarization resistance method [4]. These methods among others have also been discussed by Phelps [5]. The writer has found it desirable to use both techniques simultaneously as an aid in interpreting and checking data $[6,7]$ and this procedure was followed in the measurements about to be described.

\section{Experimental Procedure}

\subsection{Preparation and Exposure of Specimens}

The binary alloys were forged and heat treated by the Armco Steel Corporation. Their compositions according to analysis are shown in table 1 . Forgings, 0.875 in. $\times 0.875(2.2 \mathrm{~cm} \times 2.2 \mathrm{~cm})$ in cross section, were machined into specimens $0.625 \mathrm{in} .(1.59 \mathrm{~cm})$ diam $\times 12$ in. $(30 \mathrm{~cm})$ long. A hole, 0.25 in. $(6.3 \mathrm{~mm})$ diam centered 0.32 in. $(8.1 \mathrm{~mm})$ from one end, was drilled through the specimen to permit insertion of a Nichrome wire, No. $30 \mathrm{~B} \& \mathrm{~S}$ gage, 0.010 in. $(0.25 \mathrm{~mm})$ diam, which served as a loop to hold the specimen in suspension below the surface of the corrodent. All edges were 
rounded, particularly at the hole, in order to assure accuracy in weight loss measurements. This precaution also prevented nicking of the suspension wire and provided good electrical contact as this wire also conducted the polarizing current.

The method used in suspending the specimens and the reasons therefor were previously described [1]. The Nichrome was always cathodic to the specimens, even to the nickel specimen, and galvanic action, if any, was insignificant as previously observed with the $\mathrm{Fe}-\mathrm{Cr}$ alloys.

Before exposure, the specimens were degreased, scrubbed with scouring powder, rinsed, rubbed with fine-grit abrasive, scrubbed under running hot water, dried by air-blast and then weighed to the nearest $2 \mathrm{mg}$.

Twelve specimens, each of different composition (table 1) were exposed to Washington, D.C. city water to which was added 3 percent by weight of sodium chloride. The salt water was contained by an open cylindrical vat, 66 in. $(16.7 \mathrm{dm})$ diam. The depth of the water was maintained at $18 \mathrm{in}$. and the volume of water about 265 gal. The specimens, about 13 in. $(33 \mathrm{~cm})$ apart, were staggered and suspended in two rows across the center of the vat, the tops of the specimens being 2 in. $(5 \mathrm{~cm})$ below the water surface. Electrical contact with a given specimen was made through a terminal strip mounted on the outside of the vat from which wires were permanently connected to the Nichrome suspension loops by battery clips. The temperature of the water was not controlled but was measured regularly during exposure.

TABLE 1. Composition of alloys

\begin{tabular}{c|r|r}
\hline \hline \multirow{2}{*}{ Specimen } & \multicolumn{2}{|c}{ Compositon, percent* } \\
\cline { 2 - 3 } & & \\
& Iron & Nickel \\
\hline & & \\
1 & 100 & 0 \\
2 & 97 & 3 \\
3 & 95 & 5 \\
4 & 91 & 10 \\
5 & 85 & 16 \\
6 & 81 & 20 \\
7 & 70 & 30 \\
8 & 64 & 36 \\
9 & 49 & 50 \\
10 & 43 & 57 \\
11 & 21 & 81 \\
12 & 0 & 100 \\
\hline
\end{tabular}

*Analyzed by x-ray fluorescence techniques for iron and nickel in each specimen. Iron and nickel were determined separately. Values as measured were within \pm 0.5 percent and are rounded off to the nearest 1 percent. Two specimens, 1 and 11 , were analyzed by a qualitative spectrochemical method for impurities, resulting in the following: Specimen by a qualitative spectrochemical method for impurities, resulting in the following: Specimen had Si between 0.1-1.0 percent, Cu, Co, Ti, each between $0.01-0.1$ percent, Al, Mn each $<0.01$ percent.

\subsection{Electrical Measurements}

Potentials were measured with reference to a saturated calomel half-cell. Contact between the salt water and the half-cell was by an agar-salt bridge in the form of a $5-\mathrm{ft}(152 \mathrm{~cm})$ length of flexible tubing containing a mixture of agar and potassium chloride. The electrical continuity of the agar-salt bridge was assured by a cotton cord saturated with potassium chloride. The cord extended the entire length of the tube enveloped by the agar-salt mixture. The end of the tube was placed into the water through a sleeve mounted about $6 \mathrm{in}$. $(15 \mathrm{~cm})$ from the wall inside of the vat. The distance between the tip of the salt-bridge and a specimen varied between $18 \mathrm{in} .(46 \mathrm{~cm})$ and $40 \mathrm{in}$. (101 cm), depending on the location of the specimen. When electrical measurements were not in progress, the salt-bridge was removed from the water. When polarization measurements were being made, auxiliary electrodes consisting of two strips of zinc sheet, 4 in. $(10 \mathrm{~cm})$ wide $\times 18$ in. $(46 \mathrm{~cm})$ long, were hung over the wall of the vat.

Measurements were made on about 22 occasions during the exposure period of 210 days. The measurements involved corrosion potential and the running of cathodic and anodic polarization curves. For a given specimen, an interval of several hours, sometimes $24 \mathrm{hr}$, was permitted between cathodic and anodic polarization runs, not necessarily in that order, but usually so.

Corrosion potentials were measured with a high resistance voltmeter and polarization was measured and recorded with a two-pen (current and potential) strip-chart recorder. The length of time required for obtaining a polarization curve varied from about 15 to $30 \mathrm{~min}$. Most of the polarization data were obtained by using the galvanodynamic method and about 25 percent using a potentiodynamic method for comparison. The schematic circuit diagrams for these methods are shown in figures 1 and 2, respectively. Both circuits incorporate the Holler bridge for balancing out undesirable voltage drop (IR) from the recorded potentials [8]. In figure 1 , the polarizing current is steadily increased by varying the applied voltage at a linear rate by means of the ten-turn motor-driven potentiometer $R_{1}$ with resistor $R_{3}$ set for a predetermined range of polarizing current. In figure 2 , initially the applied voltage between the specimen and the reference electrode is manually adjusted by setting $R_{4}$ to a value equal to the corrosion potential after which $R_{4}$ becomes motor-driven and sweeps the range of potential required for polarization while $R_{3}$ is set at a comparatively low value of resistance so as to not unduly limit the applied current. In viewing the recorder charts, the break in the curve is more evident on the potential plot than on the current plot with the galvanodynamic method, while the reverse is true when the potential sweep circuit (fig. 2) is used.

\subsection{Removal of Corrosion Products}

Following removal from the salt water, the specimens were held under running hot water and scrubbed with a stiff fiber-bristle brush. They were then placed into an ultrasonic cleaning tank (for $10 \mathrm{~min}$ ) containing a 10 percent solution, at $150{ }^{\circ} \mathrm{F}$, of ammonium citrate made alkaline $(p \mathrm{H} 9-10)$ by the addition of ammonium hydroxide. Then, the specimens were again brushed under running hot water, dried under an air 


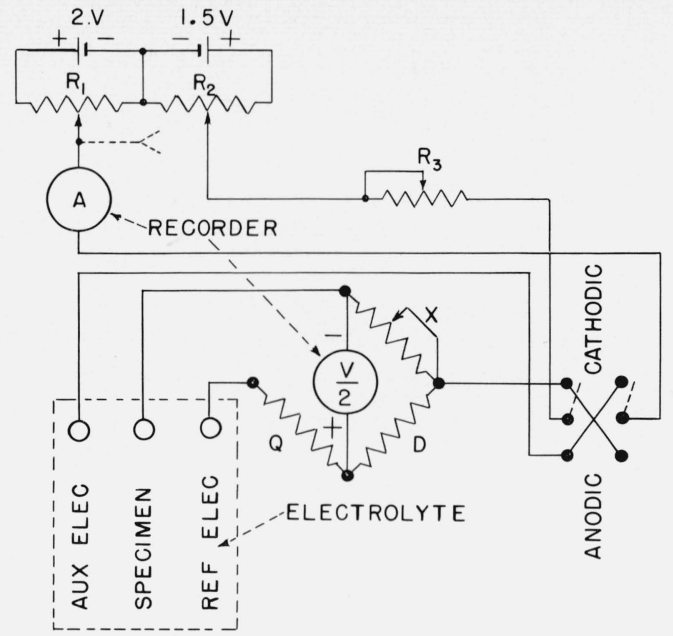

Figure 1. Polarization circuit-galvanodynamic method. $R_{1}=25 \Omega-10$ turn (motor driven -0.2 RPM), $R_{2}=100 \Omega 10$ turn, $R_{3}, 10,000 \Omega, X=100 \Omega$ -10 turn, $Q=D=100,000 \Omega$.

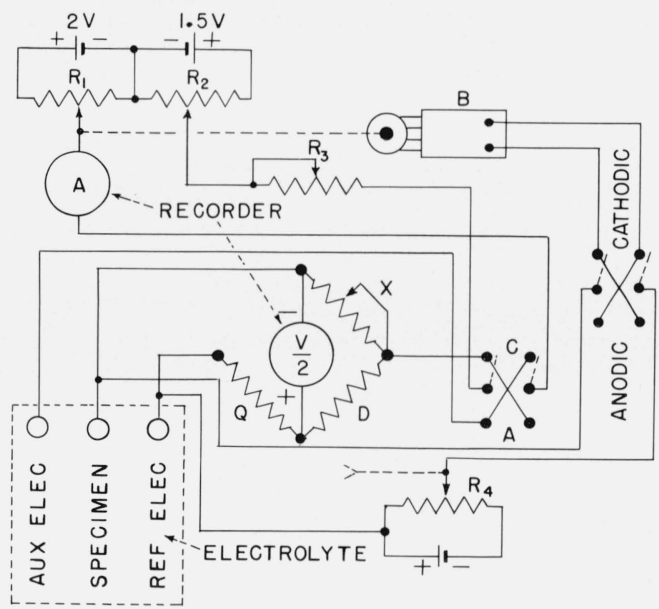

Figure 2. Polarization circuit-potentiodynamic method. $R_{1}=50 \Omega-10$ turn (motor driven-variable speed-reversible), $R_{2}=100 \Omega 10$ turn, $R$ $=10,000 \Omega, R_{4}=25 \Omega-10$ turn (motor driven -0.2 RPM reversible), $X=100 \Omega-10$ turn, $Q=D=100,000 \Omega, B=$ motor (controlled by voltage differential).

blast and weighed to the nearest $2 \mathrm{mg}$. After repeating this procedure the third time, there was no significant change in weight; the final weights were then subtracted from the original weights in computing the actual metal loss attributed to corrosion.

\section{Results and Discussion}

On the 210th day of exposure the specimens were removed from the salt water. Although the object of the experimental work was primarily that of evaluating the corrosion rate measuring techniques, the data in table 2 show how the results to be described are related to the apparent areas corroded and to the depths of the pits. Note, that all apparent corrosion on the nickel (specimen 12) seems to have been confined to one pit.

Polarization curves from data on recorder charts obtained on the $202 \mathrm{~d}$ day of exposure are shown in figures 3 and 4 on semilogarithmic and rectangular coordinates, respectively. While such data, ordinarily, are shown on semilogarithmic coordinates, the rectangular plot helps to verify the break in the curve and the value of applied current at which it occurs. The absence of a break on the latter would place doubt on the extrapolated semilogarithmic value. The values of $I_{p}$ (break in the cathodic curve) and of $I_{q}$ (break in the anodic curve) chosen in calculating the corrosion currents (table 3 ) are marked $I_{p}$ and $I_{q}$ in figures 3 and 4 and are indicated by vertical dashes (where dashed lines intersect). It will be noted that there is reasonably good agreement between figures 3 and 4 for a given specimen in the values of $I_{p}$, but apparently not as good agreement in the values of $I_{q}$.

TABLE 2. Appearance of the binary alloys of nickel and iron after cleaning which followed 210 days of exposure to salt water

\begin{tabular}{|c|c|c|}
\hline Specimen & $\begin{array}{c}\text { Apparent } \\
\text { area } \\
\text { corroded }\end{array}$ & Remarks, pit depths \\
\hline $1(100 \mathrm{Fe})$ & $\begin{array}{c}\text { Percent } \\
85\end{array}$ & General corrosion $(0-3$ mils*). \\
\hline $2(3 \mathrm{Ni})$ & 70 & General corrosion ( $0-3$ mils $)$, except for one pit $(5$ mils $)$. \\
\hline $3(5 \mathrm{Ni})$ & 80 & General corrosion $(0-3$ mils $)$. \\
\hline $4(10 \mathrm{Ni})$ & 75 & General corrosion $(0-3$ mils $)$. \\
\hline $5(16 \mathrm{Ni})$ & 65 & General corrosion ( $0-5$ mils $)$. \\
\hline $6(20 \mathrm{Ni})$ & 50 & General corrosion (0-8 mils). \\
\hline $7(30 \mathrm{Ni})$ & 40 & $\begin{array}{l}\text { Lower } 4.5 \mathrm{in} .(11 \mathrm{~cm}) \text { (opposite suspension end) of specimen } \\
\text { length not corroded, otherwise }- \text { general corrosion }(0-8 \text { mils). }\end{array}$ \\
\hline $8(36 \mathrm{Ni})$ & 50 & Spotty corrosion to 10 -mil depths. \\
\hline $9(50 \mathrm{Ni})$ & 15 & $\begin{array}{l}8 \mathrm{in} .(20 \mathrm{~cm}) \text { of the specimen measured from the lower end was } \\
\text { not corroded. } \\
\text { Spotty corrosion }(8-12 \text { mils }) \text { on the upper } 4 \text { in. }(10 \mathrm{~cm}) \text {. Pits to } \\
45 \text { mils in depth at the top end. }\end{array}$ \\
\hline $10(57 \mathrm{Ni})$ & $<1$ & $\begin{array}{l}\text { Scattered pits }(2-6 \text { mils }) \text { in about } 24 \text { places. One pit }(50 \text { mils }) \\
\text { at the top end. }\end{array}$ \\
\hline $11(81 \mathrm{Ni})$ & $<0.05$ & $\begin{array}{l}\text { Three pits }(5-25 \text { mils }) \text { on the surface. One pit }(50 \text { mils }) \text { inside } \\
\text { of the mounting hole. }\end{array}$ \\
\hline $12(100 \mathrm{Ni})$ & $<0.02$ & $\begin{array}{l}\text { No corrosion, except for one pit ( } 60 \text { mils deep) inside the mount- } \\
\text { ing hole. }\end{array}$ \\
\hline
\end{tabular}

${ }^{*}$ mil $=0.001$ in. $(25.4 \mu)$.

The values of $I_{q}$, pertaining to these data, selected from the rectangular coordinates are considered the more significant, except for specimens $11(81 \mathrm{Ni})$ and 12 $(100 \mathrm{Ni})$. The actual values of $I_{p}$ and $I_{q}$ were obtained before compressing the scales (particularly the ordinates) as shown in figures 3 and 4 . The data for all specimens are shown on one figure so that the reader can get an overall picture of what the curves portray for different rates of corrosion. When calculating the corrosion current (see the equation, footnote b, table 3 ), the smaller current, whether it be $I_{p}$ or $I_{q}$, is the more significant (controlling) and fortunately can be extrapolated with the greater degree of accuracy. 


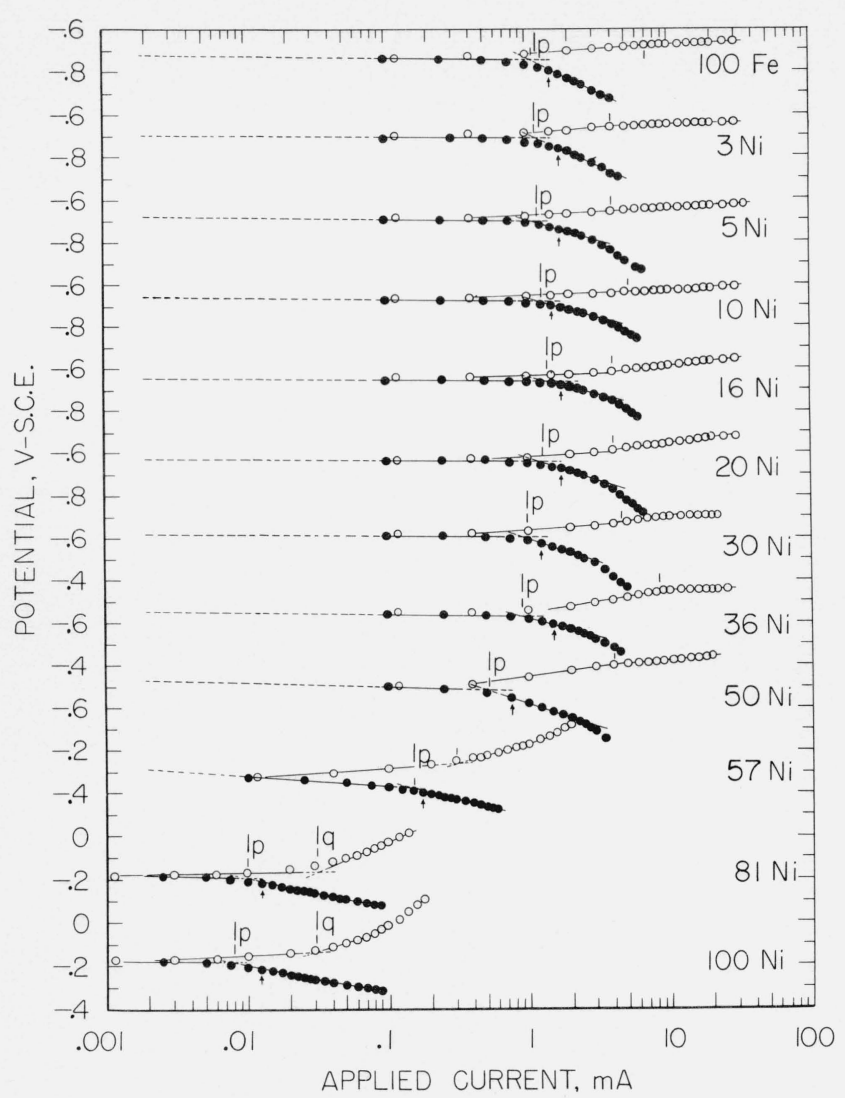

Figure 3. Polarization curves of iron, nickel, and binary alloys of nickel and iron obtained on the $202 d$ day of exposure to city water having added 3 percent by weight of sodium chloride.

NOTE: Values of $I_{p}$ and $I_{q}$ actually used for the calculations (table 3 ) are marked $I_{p}$ and NOTE: $V$ alues of $I_{p}$ and $I_{q}$ actually used for the calculations (table 3 ) are marked $I_{p}$ and
$I_{q}$ (figs. 3 and 4), for example, $I_{p}$ (fig. 3 ) is used with $I_{q}($ fig. 4 ) for the 100 Fe specimen. In the case of the $100 \mathrm{Ni}$ specimen, $I_{p}$ and $I_{q}$ of figure 3 are used, etc. The ordinates (figs. 3 and 4 ) are compressed to save space. In going up the scale, the potentials become less negative. Thus, for the $30 \mathrm{Ni}$ specimen, the corrosion potential is about $-0.58 \mathrm{~V}$ (see fig. 4).

All the values of $I_{p}$ and $I_{q}$, calculated corrosion currents, calculated weight losses, and actual weight losses for all specimens are tabulated in table 3 . In calculating weight losses, the electrochemical equivalent for ferrous iron was chosen for the alloys with less than 50 percent of nickel, and that of nickel for the alloys having 50 percent or more of nickel. Actually, the equivalent value chosen is not significant here as the difference (about 5\%) in results obtained is within the limit of accuracy with which the polarization curves can be evaluated.

In table 3, beginning with the 78th day of exposure and on through the 117th day, all data were obtained using the potentiodynamic method of polarization. It will be noted that the data pattern fits in quite well with the pattern before and after this period obtained using the galvanodynamic polarization technique. For specimens 1 through 6 , the change from $I_{q}=10 I_{p}$ to lesser values of $I_{q}$ is not believed to be significant. The potentiodynamic method offered no advantage in obtaining these data and required more instrumentation.

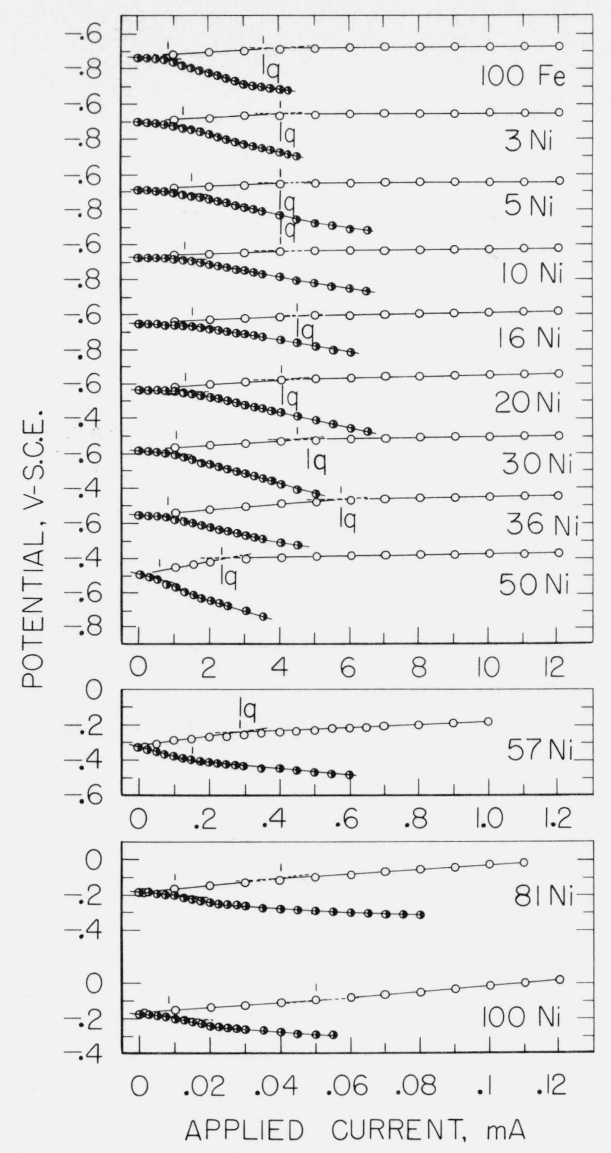

Figure 4. Same data as in figure 3, plotted on rectangular coordinates.

$\bigcirc$ anodic, cathodic. See "Note" figure 3.

Figure 5 shows how the corrosion rates vary with the nickel content and how the calculated and actual values compare. The biggest reduction in corrosion rate occurred in changing from $50 \mathrm{Ni}$ to $57 \mathrm{Ni}$. For the particular environment, nickel in amounts up to 20 percent seem to offer no advantage from the standpoint of corrosion resistance. Pettibone [9] demonstrated an advantage in the corrosion resistance of $36.53 \mathrm{Ni}$ steel over mild steel in four sea water environments for exposure periods varying from 5 to 15 years. It has also been reported that the corrosion rate of a 26 percent $\mathrm{Ni}$ alloy of iron and nickel was about onethird that of wrought iron in sea water as well as in the atmosphere [10].

When specimen 8 (36 Ni) was initially exposed, the corrosion current was about one-eighth that of the specimens with lesser amounts of nickel (table 3). Between the 4th and 7th days, the corrosion potential of specimen 8 changed from $-0.355 \mathrm{~V}$ to $-0.540 \mathrm{~V}$ (potentials are not shown in the table) and the corrosion current increased fivefold. On specimen 9 (50 $\mathrm{Ni}$ ), a low rate of corrosion prevailed through the $34 \mathrm{th}$ 
TABLE 3. Corrosion weight losses calculated from polarization data obtained on a series of alloys containing nickel and iron exposed to a 3-percent sodium chloride solution for 7 months

\begin{tabular}{|c|c|c|c|c|c|c|}
\hline \multirow{2}{*}{$\begin{array}{l}\text { Speci- } \\
\text { men }\end{array}$} & \multirow{2}{*}{$\begin{array}{l}\text { Exposure } \\
\text { time }\end{array}$} & \multicolumn{2}{|c|}{$\begin{array}{l}\text { Polarizing current } \\
\text { at break in curve }\end{array}$} & \multirow{2}{*}{$\begin{array}{c}\begin{array}{c}\text { Corrosion } \\
\text { current }^{\mathrm{b}}\end{array} \\
i_{0}\end{array}$} & \multicolumn{2}{|c|}{ Weight loss ${ }^{c}$} \\
\hline & & $\underset{I_{p}}{\text { Cathodic }}$ & $\begin{array}{c}\text { Anodic } \\
I_{q}\end{array}$ & & $\begin{array}{l}\text { Calculated } \\
\text { cumulative }\end{array}$ & Actual \\
\hline & Days & $m A$ & $m A$ & $m A$ & $m g$ & $m g$ \\
\hline$(100 \mathrm{Fe})$ & $\begin{array}{r}4 \\
14 \\
20 \\
28 \\
34 \\
41 \\
46 \\
54 \\
62 \\
70 \\
78 \\
88 \\
95 \\
102 \\
117 \\
125 \\
137 \\
145 \\
159 \\
172 \\
202 \\
210\end{array}$ & $\begin{array}{l}1.8 \\
1.0 \\
0.75 \\
1.0 \\
0.93 \\
1.1 \\
1.0 \\
0.95 \\
1.1 \\
1.2 \\
1.1 \\
1.2 \\
1.1 \\
1.3 \\
1.2 \\
1.1 \\
1.0 \\
0.80 \\
1.2 \\
1.1 \\
1.1\end{array}$ & $\begin{array}{c}10 I_{p}^{\mathrm{d}} \\
10 I_{p} \mathrm{~d} \\
10 I_{p} \mathrm{~d} \\
10 I_{p} \mathrm{~d} \\
10 I_{p} \mathrm{~d} \\
10 I_{p} \mathrm{~d} \\
10 I_{p} \mathrm{~d} \\
10 I_{p} \mathrm{~d} \\
10 I_{p} \mathrm{~d} \\
10 I_{p} \mathrm{~d} \\
6.0 \\
8.2 \\
8.0 \\
7.3 \\
7.8 \\
9.0 \\
7.0 \\
4.7 \\
4.5 \\
4.5 \\
3.5\end{array}$ & $\begin{array}{l}1.6 \\
0.91 \\
0.68 \\
0.91 \\
0.84 \\
1.0 \\
0.91 \\
0.86 \\
1.0 \\
1.1 \\
0.93 \\
1.0 \\
0.96 \\
1.1 \\
1.0 \\
0.98 \\
0.88 \\
0.68 \\
0.95 \\
0.88 \\
0.84 \\
. . .\end{array}$ & $\begin{array}{r}160 \\
470 \\
590 \\
750 \\
920 \\
1100 \\
1200 \\
1400 \\
1600 \\
1800 \\
2000 \\
2200 \\
2400 \\
2600 \\
3000 \\
3200 \\
3400 \\
3600 \\
3900 \\
4200 \\
4800 \\
5000\end{array}$ & 4590 \\
\hline$\left(3^{2} \mathrm{Ni}\right)$ & $\begin{array}{r}4 \\
14 \\
20 \\
28 \\
34 \\
41 \\
46 \\
54 \\
62 \\
70 \\
77 \\
88 \\
95 \\
102 \\
117 \\
125 \\
137 \\
145 \\
159 \\
172 \\
202 \\
210\end{array}$ & $\begin{array}{l}1.6 \\
1.3 \\
0.95 \\
1.2 \\
1.1 \\
1.1 \\
1.0 \\
0.95 \\
1.2 \\
1.3 \\
1.3 \\
1.3 \\
1.2 \\
1.3 \\
1.4 \\
0.95 \\
1.3 \\
1.1 \\
1.3 \\
1.2 \\
1.1\end{array}$ & $\begin{array}{c}10 I_{p} \mathrm{~d} \\
10 I_{p} \mathrm{~d} \\
10 p_{p} \mathrm{~d} \\
10 I_{p} \mathrm{~d} \\
10 I_{p} \mathrm{~d} \\
10 I_{p} \mathrm{~d} \\
10 I_{p} \mathrm{~d} \\
10 I_{p} \mathrm{~d} \\
10 I_{p} \mathrm{~d} \\
10 I_{p} \mathrm{~d} \\
7.5 \\
8.0 \\
7.5 \\
6.8 \\
8.8 \\
6.0 \\
6.0 \\
4.0 \\
9.0 \\
4.0 \\
4.0\end{array}$ & $\begin{array}{l}1.4 \\
1.2 \\
0.85 \\
1.1 \\
1.0 \\
1.0 \\
0.91 \\
0.85 \\
1.1 \\
1.2 \\
1.1 \\
1.1 \\
1.0 \\
1.1 \\
1.2 \\
0.82 \\
1.1 \\
0.86 \\
1.1 \\
0.92 \\
0.86\end{array}$ & $\begin{array}{r}140 \\
460 \\
610 \\
810 \\
970 \\
1100 \\
1300 \\
1400 \\
1600 \\
1900 \\
2100 \\
2400 \\
2500 \\
2700 \\
3200 \\
3400 \\
3600 \\
3800 \\
4200 \\
4500 \\
5200 \\
5300\end{array}$ & 4660 \\
\hline (5 $\stackrel{3}{\mathrm{Ni}})$ & $\begin{array}{r}4 \\
14 \\
20 \\
28 \\
34 \\
41 \\
46 \\
54 \\
62 \\
70 \\
78 \\
88 \\
95 \\
102 \\
118 \\
125 \\
137 \\
145 \\
159 \\
172 \\
202 \\
210\end{array}$ & $\begin{array}{l}1.6 \\
1.0 \\
0.80 \\
1.2 \\
1.1 \\
1.3 \\
1.1 \\
0.98 \\
1.3 \\
1.5 \\
1.3 \\
1.2 \\
1.5 \\
1.5 \\
1.3 \\
1.1 \\
1.3 \\
1.2 \\
1.3 \\
1.2 \\
1.2\end{array}$ & $\begin{array}{c}10 I_{p}^{\mathrm{d}} \\
10 I_{p} \mathrm{~d} \\
10 I_{p} \mathrm{~d} \\
10 I_{p} \mathrm{~d} \\
10 I_{p} \mathrm{~d} \\
10 I_{p} \mathrm{~d} \\
10 I_{p} \mathrm{~d} \\
10 I_{p} \mathrm{~d} \\
10 I_{p} \mathrm{~d} \\
10 I_{p} \mathrm{~d} \\
8 \\
8.3 \\
7.5 \\
7.3 \\
8.0 \\
7.0 \\
9.0 \\
5.0 \\
4.5 \\
4.2 \\
4.0 \\
\end{array}$ & $\begin{array}{l}1.4 \\
0.91 \\
0.73 \\
1.1 \\
1.0 \\
1.2 \\
1.0 \\
0.89 \\
1.2 \\
1.4 \\
1.1 \\
1.0 \\
1.3 \\
1.2 \\
1.1 \\
0.96 \\
1.1 \\
0.97 \\
1.0 \\
0.93 \\
0.92\end{array}$ & $\begin{array}{r}140 \\
410 \\
540 \\
720 \\
890 \\
1100 \\
1200 \\
1400 \\
1600 \\
1900 \\
2100 \\
2400 \\
2600 \\
2800 \\
3300 \\
3400 \\
3700 \\
3900 \\
4300 \\
4600 \\
5300 \\
5500\end{array}$ & \\
\hline
\end{tabular}

TABLE 3. Corrosion weight losses calculated from polarization data obtained on a series of alloys containing nickel and iron exposed to a 3-percent sodium chloride solution for 7 monthsContinued

\begin{tabular}{|c|c|c|c|c|c|c|}
\hline \multirow{2}{*}{$\begin{array}{c}\text { Speci- } \\
\text { men }\end{array}$} & \multirow{2}{*}{$\begin{array}{c}\text { Exposure } \\
\text { time }\end{array}$} & \multicolumn{2}{|c|}{$\begin{array}{l}\text { Polarizing current } \\
\text { at break in curve }{ }^{\text {a }}\end{array}$} & \multirow{2}{*}{$\begin{array}{c}\begin{array}{c}\text { Corrosion } \\
\text { current }^{b}\end{array} \\
i_{0}\end{array}$} & \multicolumn{2}{|c|}{ Weight loss ${ }^{c}$} \\
\hline & & $\begin{array}{l}\text { Cathodic } \\
\quad I_{p}\end{array}$ & $\underset{I_{q}}{\text { Anodic }}$ & & $\begin{array}{l}\text { Calculated } \\
\text { cumulative }\end{array}$ & Actual \\
\hline & Days & $m A$ & $m A$ & $m A$ & $m g$ & $m g$ \\
\hline$(10 \mathrm{~N}$ i $)$ & $\begin{array}{r}4 \\
14 \\
20 \\
28 \\
34 \\
41 \\
46 \\
55 \\
62 \\
70 \\
78 \\
88 \\
95 \\
102 \\
117 \\
125 \\
137 \\
145 \\
159 \\
172 \\
202 \\
210\end{array}$ & $\begin{array}{l}1.5 \\
1.3 \\
1.0 \\
1.3 \\
1.3 \\
1.1 \\
1.2 \\
1.2 \\
1.2 \\
1.3 \\
1.2 \\
1.2 \\
1.2 \\
1.3 \\
1.3 \\
1.2 \\
1.5 \\
1.2 \\
1.3 \\
1.3 \\
1.3\end{array}$ & $\begin{array}{c}10 I_{p} \mathrm{~d} \\
10 I_{p} \\
10 I_{p} \\
10 I_{p} \\
10 \mathrm{~d} \\
10 I_{p} \mathrm{~d}^{2} \\
10 I_{p} \mathrm{~d} \\
10 I_{p} \mathrm{~d} \\
10 I_{p} \mathrm{~d} \\
10 I_{p} \mathrm{~d} \\
10 I_{p} \mathrm{~d}^{2} \\
7.5 \\
9.0 \\
8.0 \\
8.0 \\
7.0 \\
7.0 \\
14.0 \\
5.0 \\
4.0 \\
4.2 \\
4.0\end{array}$ & $\begin{array}{l}1.4 \\
1.2 \\
0.91 \\
1.2 \\
1.2 \\
1.0 \\
1.1 \\
1.1 \\
1.1 \\
1.2 \\
1.0 \\
1.1 \\
1.0 \\
1.1 \\
1.1 \\
1.0 \\
1.4 \\
0.97 \\
0.98 \\
0.99 \\
0.98\end{array}$ & $\begin{array}{r}140 \\
470 \\
630 \\
830 \\
1000 \\
1200 \\
1300 \\
1600 \\
1800 \\
2000 \\
2200 \\
2500 \\
2600 \\
2800 \\
3200 \\
3400 \\
3800 \\
4000 \\
4400 \\
4700 \\
5400 \\
5600\end{array}$ & 4880 \\
\hline$\stackrel{5}{(16} \stackrel{\mathrm{Ni}}{ })$ & $\begin{array}{r}4 \\
14 \\
20 \\
28 \\
34 \\
41 \\
46 \\
55 \\
62 \\
70 \\
78 \\
88 \\
95 \\
102 \\
117 \\
125 \\
137 \\
145 \\
159 \\
172 \\
202 \\
210\end{array}$ & $\begin{array}{l}1.9 \\
1.4 \\
1.2 \\
1.5 \\
1.0 \\
1.2 \\
1.2 \\
1.3 \\
1.5 \\
1.5 \\
1.4 \\
1.5 \\
1.4 \\
1.7 \\
1.6 \\
1.4 \\
1.5 \\
1.5 \\
1.4 \\
1.5 \\
1.4\end{array}$ & $\begin{array}{c}10 I_{p}{ }^{\mathrm{d}} \\
10 I{ }^{\mathrm{d}} \\
10 I_{p}{ }^{\mathrm{d}} \\
10 I_{p}{ }^{\mathrm{d}} \\
10 I_{p}{ }^{\mathrm{d}} \\
10 I_{p}{ }^{\mathrm{d}} \\
10 I_{p} \mathrm{~d} \\
10 I_{\mathrm{d}} \\
10 I_{p}{ }^{\mathrm{d}} \\
10 I_{p}{ }^{\mathrm{d}} \\
8.7 \\
9.0 \\
8.0 \\
7.1 \\
8.4 \\
5.0 \\
4.5 \\
4.0 \\
4.0 \\
4.5\end{array}$ & $\begin{array}{l}1.7 \\
1.3 \\
1.1 \\
1.4 \\
0.90 \\
1.1 \\
1.1 \\
1.2 \\
1.4 \\
1.4 \\
1.2 \\
1.3 \\
1.2 \\
1.4 \\
1.3 \\
1.1 \\
1.1 \\
1.1 \\
1.0 \\
1.1 \\
1.1\end{array}$ & $\begin{array}{r}170 \\
550 \\
720 \\
980 \\
1100 \\
1300 \\
1500 \\
1700 \\
1900 \\
2200 \\
2500 \\
2800 \\
3000 \\
3200 \\
3700 \\
4000 \\
4300 \\
4500 \\
4900 \\
5200 \\
6100 \\
6300\end{array}$ & 5350 \\
\hline$(20 \stackrel{6}{\mathrm{Ni}})$ & $\begin{array}{r}5 \\
12 \\
20 \\
28 \\
34 \\
41 \\
46 \\
55 \\
62 \\
70 \\
77 \\
88 \\
95 \\
102 \\
117 \\
125 \\
137 \\
145 \\
159 \\
172 \\
202 \\
210\end{array}$ & $\begin{array}{l}2.0 \\
1.5 \\
1.1 \\
1.5 \\
1.2 \\
1.1 \\
1.1 \\
1.2 \\
1.1 \\
1.2 \\
1.2 \\
1.3 \\
1.3 \\
1.3 \\
1.5 \\
1.1 \\
1.4 \\
1.0 \\
1.3 \\
1.2 \\
1.3\end{array}$ & 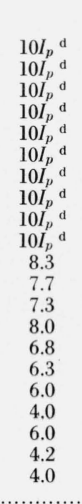 & $\begin{array}{l}1.8 \\
1.4 \\
1.0 \\
1.4 \\
1.1 \\
1.0 \\
1.0 \\
1.1 \\
1.0 \\
1.1 \\
1.0 \\
1.1 \\
1.1 \\
1.1 \\
1.2 \\
0.94 \\
1.1 \\
0.80 \\
1.1 \\
0.93 \\
0.98\end{array}$ & $\begin{array}{r}220 \\
500 \\
740 \\
990 \\
1200 \\
1400 \\
1500 \\
1700 \\
1900 \\
2100 \\
2300 \\
2600 \\
2800 \\
3000 \\
3400 \\
3600 \\
3900 \\
4100 \\
4400 \\
4800 \\
5500 \\
5700\end{array}$ & 4440 \\
\hline
\end{tabular}


TABLE 3. Corrosion weight losses calculated from polarization data obtained on a series of alloys containing nickel and iron exposed to a 3-percent sodium chloride solution for 7 monthsContinued

\begin{tabular}{|c|c|c|c|c|c|c|}
\hline \multirow{2}{*}{$\begin{array}{c}\text { Speci- } \\
\text { men }\end{array}$} & \multirow{2}{*}{$\begin{array}{c}\text { Exposure } \\
\text { time }\end{array}$} & \multicolumn{2}{|c|}{$\begin{array}{l}\text { Polarizing current } \\
\text { at break in curve }\end{array}$} & \multirow{2}{*}{$\begin{array}{c}\begin{array}{c}\text { Corrosion } \\
\text { current }^{\mathrm{b}}\end{array} \\
i_{0}\end{array}$} & \multicolumn{2}{|c|}{ Weight loss ${ }^{c}$} \\
\hline & & $\begin{array}{c}\text { Cathodic } \\
I_{p}\end{array}$ & $\begin{array}{c}\text { Anodic } \\
I_{q}\end{array}$ & & $\begin{array}{l}\text { Calculated } \\
\text { cumulative }\end{array}$ & Actual \\
\hline & Days & $m A$ & $m A$ & $m A$ & $m g$ & $m g$ \\
\hline$\left.{ }^{7}{ }^{7} \mathrm{Ni}\right)$ & $\begin{array}{r}4 \\
12 \\
20 \\
28 \\
34 \\
40 \\
47 \\
55 \\
62 \\
70 \\
78 \\
88 \\
95 \\
102 \\
117 \\
125 \\
137 \\
145 \\
159 \\
172 \\
202 \\
210\end{array}$ & $\begin{array}{l}1.7 \\
1.5 \\
1.0 \\
1.2 \\
1.1 \\
1.1 \\
0.93 \\
1.1 \\
1.1 \\
1.0 \\
1.1 \\
1.2 \\
1.1 \\
1.2 \\
1.0 \\
0.95 \\
1.0 \\
0.90 \\
0.98 \\
1.1 \\
1.0\end{array}$ & $\begin{array}{c}5.0 \\
7.5 \\
7.0 \\
10 I_{p} \\
10 I_{p} \\
10 I_{p} \\
10 I_{p} \\
10 I_{p}{ }^{2} \\
5.0 \\
6.0 \\
9.2 \\
11.5 \\
8.0 \\
9.0 \\
8.8 \\
5.3 \\
6.5 \\
4.0 \\
2.5 \\
2.5 \\
4.5\end{array}$ & $\begin{array}{l}1.3 \\
1.1 \\
0.87 \\
1.1 \\
1.0 \\
1.0 \\
0.85 \\
1.0 \\
0.90 \\
0.86 \\
0.98 \\
1.1 \\
0.97 \\
1.1 \\
0.90 \\
0.81 \\
0.87 \\
0.74 \\
0.70 \\
0.76 \\
0.82\end{array}$ & $\begin{array}{r}130 \\
370 \\
570 \\
760 \\
920 \\
1100 \\
1200 \\
1400 \\
1600 \\
1800 \\
1900 \\
2200 \\
2400 \\
2500 \\
2900 \\
3100 \\
3300 \\
3500 \\
3700 \\
4000 \\
4600 \\
4700\end{array}$ & 4100 \\
\hline$(36 \stackrel{8}{\mathrm{Ni}})$ & $\begin{array}{r}4 \\
7 \\
12 \\
21 \\
29 \\
34 \\
41 \\
47 \\
55 \\
62 \\
70 \\
78 \\
88 \\
95 \\
102 \\
117 \\
125 \\
137 \\
145 \\
159 \\
173 \\
202 \\
210\end{array}$ & $\begin{array}{l}0.20 \\
1.1 \\
1.4 \\
0.75 \\
1.3 \\
0.90 \\
1.0 \\
0.80 \\
0.90 \\
0.90 \\
1.0 \\
1.0 \\
1.1 \\
1.2 \\
1.2 \\
1.2 \\
1.2 \\
0.50 \\
0.90 \\
1.3 \\
0.90 \\
0.90 \\
\ldots \ldots . .\end{array}$ & $\begin{array}{l}0.90 \\
4.4 \\
8.2 \\
5.0 \\
5.5 \\
4.3 \\
5.8 \\
3.7 \\
5.5 \\
5.0 \\
5.0 \\
5.5 \\
6.0 \\
5.0 \\
4.8 \\
5.0 \\
6.0 \\
6.5 \\
5.2 \\
6.0 \\
5.0 \\
5.7\end{array}$ & $\begin{array}{l}0.16 \\
0.88 \\
1.2 \\
0.65 \\
1.1 \\
0.74 \\
0.85 \\
0.66 \\
0.77 \\
0.76 \\
0.83 \\
0.85 \\
0.93 \\
0.97 \\
0.96 \\
0.97 \\
1.0 \\
0.79 \\
0.77 \\
1.1 \\
0.76 \\
0.78\end{array}$ & $\begin{array}{r}16 \\
55 \\
180 \\
390 \\
560 \\
680 \\
820 \\
930 \\
1100 \\
1200 \\
1400 \\
1500 \\
1800 \\
1900 \\
2100 \\
2500 \\
2600 \\
2900 \\
3100 \\
3400 \\
3700 \\
4300 \\
4400\end{array}$ & 3110 \\
\hline$(50 \stackrel{9}{\mathrm{Ni}})$ & $\begin{array}{r}4 \\
7 \\
12 \\
18 \\
28 \\
34 \\
40 \\
46 \\
54 \\
62 \\
70 \\
78 \\
88 \\
95 \\
102 \\
117 \\
125 \\
137 \\
145 \\
159 \\
173 \\
202 \\
210\end{array}$ & $\begin{array}{l}0.18 \\
0.11 \\
0.15 \\
0.32 \\
0.26 \\
0.29 \\
1.4 \\
1.3 \\
0.75 \\
1.0 \\
1.0 \\
0.90 \\
0.82 \\
0.75 \\
0.88 \\
0.60 \\
0.55 \\
0.65 \\
0.60 \\
0.60 \\
0.67 \\
0.52\end{array}$ & $\begin{array}{l}0.30 \\
0.11 \\
0.30 \\
0.14 \\
0.30 \\
0.25 \\
3.0 \\
3.0 \\
2.1 \\
2.5 \\
6.0 \\
6.0 \\
6.5 \\
6.5 \\
5.9 \\
6.8 \\
2.5 \\
4.0 \\
2.8 \\
2.0 \\
2.5 \\
2.3 \\
2.3\end{array}$ & $\begin{array}{l}0.11 \\
0.055 \\
0.10 \\
0.097 \\
0.14 \\
0.13 \\
0.95 \\
0.91 \\
0.55 \\
0.71 \\
0.85 \\
0.78 \\
0.73 \\
0.67 \\
0.76 \\
0.55 \\
0.45 \\
0.56 \\
0.49 \\
0.46 \\
0.53 \\
0.42\end{array}$ & $\begin{array}{r}12 \\
18 \\
28 \\
43 \\
75 \\
96 \\
180 \\
330 \\
480 \\
610 \\
780 \\
950 \\
1100 \\
1300 \\
1400 \\
1700 \\
1800 \\
1900 \\
2000 \\
2200 \\
2400 \\
2700 \\
2800\end{array}$ & 2860 \\
\hline
\end{tabular}

a See the text.

$i_{0}=I_{p} \cdot I_{q} /\left(I_{p}+I_{q}\right)$.

${ }^{\mathrm{c}}$ Calculated weight loss $(\mathrm{g})=K t i, K=$ electrochemical equivalent (for specimens $1-8$, assumed $K=2.8938 \times 10^{-4} \mathrm{~g} /$ coulomb; for specimens $9-12$, assumed $K=3.0409 \times 10^{-4}$ $\mathrm{g} /$ coulomb; $i=$ average of corrosion currents (A) for the exposure period $(t$ in sec) between successive readings). The values of $i_{0}$ at the beginning and end of exposure are taken as the initial and final values, respectively, as calculated.

d Assumed.
TABLE 3. Corrosion weight losses calculated from polarization data obtained on a series of alloys containing nickel and iron exposed to a 3-percent sodium chloride solution for 7 monthsContinued

\begin{tabular}{|c|c|c|c|c|c|c|}
\hline \multirow{2}{*}{$\begin{array}{c}\text { Speci- } \\
\text { men }\end{array}$} & \multirow{2}{*}{$\begin{array}{l}\text { Exposure } \\
\text { time }\end{array}$} & \multicolumn{2}{|c|}{$\begin{array}{l}\text { Polarizing current } \\
\text { at break in curve }\end{array}$} & \multirow{2}{*}{$\begin{array}{c}\begin{array}{c}\text { Corrosion } \\
\text { current }^{\mathrm{b}}\end{array} \\
i_{0}\end{array}$} & \multirow{2}{*}{$\begin{array}{l}\text { Weight } \\
\begin{array}{l}\text { Calculated } \\
\text { cumulative }\end{array}\end{array}$} & \multirow{2}{*}{$\begin{array}{l}\operatorname{loss}^{c} \\
\text { Actual }\end{array}$} \\
\hline & & $\begin{array}{c}\text { Cathodic } \\
I_{p}\end{array}$ & $\begin{array}{c}\text { Anodic } \\
I_{q}\end{array}$ & & & \\
\hline & Days & $m A$ & $m A$ & $m A$ & $m g$ & $m g$ \\
\hline $\begin{array}{c}10 \\
(57 \mathrm{Ni})\end{array}$ & $\begin{array}{r}4 \\
7 \\
12 \\
21 \\
29 \\
34 \\
40 \\
46 \\
54 \\
62 \\
70 \\
78 \\
88 \\
95 \\
102 \\
117 \\
125 \\
137 \\
146 \\
159 \\
173 \\
202 \\
210\end{array}$ & $\begin{array}{l}0.10 \\
0.08 \\
0.18 \\
0.20 \\
0.15 \\
0.13 \\
0.29 \\
0.15 \\
0.15 \\
0.15 \\
0.21 \\
0.20 \\
0.18 \\
0.16 \\
0.14 \\
0.17 \\
0.13 \\
0.11 \\
0.17 \\
0.16 \\
0.13 \\
0.15\end{array}$ & $\begin{array}{l}0.25 \\
0.13 \\
0.32 \\
0.09 \\
0.13 \\
0.12 \\
0.14 \\
0.15 \\
0.19 \\
0.25 \\
0.41 \\
0.35 \\
0.25 \\
0.25 \\
0.41 \\
0.40 \\
0.56 \\
0.55 \\
0.38 \\
0.30 \\
0.25 \\
0.28\end{array}$ & $\begin{array}{l}0.071 \\
0.049 \\
0.11 \\
0.062 \\
0.07 \\
0.065 \\
0.094 \\
0.075 \\
0.084 \\
0.094 \\
0.14 \\
0.13 \\
0.10 \\
0.098 \\
0.10 \\
0.12 \\
0.11 \\
0.092 \\
0.12 \\
0.10 \\
0.085 \\
0.097\end{array}$ & $\begin{array}{l}7.5 \\
12 \\
23 \\
43 \\
57 \\
66 \\
78 \\
91 \\
110 \\
130 \\
150 \\
180 \\
210 \\
230 \\
250 \\
290 \\
320 \\
350 \\
370 \\
410 \\
440 \\
510 \\
530\end{array}$ & 332 \\
\hline$(811 \mathrm{Ni})$ & $\begin{array}{r}4 \\
7 \\
12 \\
18 \\
29 \\
34 \\
40 \\
46 \\
54 \\
62 \\
70 \\
78 \\
88 \\
95 \\
102 \\
117 \\
125 \\
137 \\
145 \\
159 \\
173 \\
202 \\
210\end{array}$ & $\begin{array}{l}0.036 \\
0.009 \\
0.025 \\
0.011 \\
0.010 \\
0.0095 \\
0.011 \\
0.010 \\
0.012 \\
0.009 \\
0.010 \\
0.011 \\
0.012 \\
0.012 \\
0.011 \\
0.012 \\
0.0085 \\
0.0095 \\
0.011 \\
0.0082 \\
0.012 \\
0.010 \\
\ldots \ldots \ldots \ldots\end{array}$ & $\begin{array}{l}0.070 \\
0.010 \\
0.027 \\
0.019 \\
0.014 \\
0.016 \\
0.020 \\
0.018 \\
0.022 \\
0.022 \\
0.027 \\
0.027 \\
0.033 \\
0.030 \\
0.040 \\
0.042 \\
0.027 \\
0.026 \\
0.026 \\
0.025 \\
0.030 \\
0.030\end{array}$ & $\begin{array}{l}0.024 \\
0.0047 \\
0.013 \\
0.007 \\
0.0059 \\
0.0060 \\
0.0071 \\
0.0064 \\
0.0078 \\
0.0064 \\
0.0073 \\
0.0078 \\
0.0088 \\
0.0086 \\
0.0085 \\
0.0094 \\
0.0064 \\
0.0070 \\
0.0077 \\
0.0062 \\
0.0086 \\
0.0075\end{array}$ & $\begin{array}{l}2.5 \\
3.7 \\
4.9 \\
6.5 \\
8.4 \\
9.2 \\
10 \\
11 \\
13 \\
14 \\
16 \\
17 \\
20 \\
21 \\
23 \\
26 \\
28 \\
30 \\
32 \\
34 \\
37 \\
43 \\
45\end{array}$ & 61 \\
\hline $\begin{array}{c}12 \\
(100 \mathrm{Ni})\end{array}$ & $\begin{array}{r}4 \\
7 \\
12 \\
18 \\
29 \\
34 \\
40 \\
46 \\
54 \\
62 \\
70 \\
78 \\
88 \\
95 \\
102 \\
117 \\
125 \\
138 \\
145 \\
159 \\
173 \\
202 \\
210\end{array}$ & $\begin{array}{l}0.050 \\
0.0070 \\
0.010 \\
0.0088 \\
0.010 \\
0.0095 \\
0.010 \\
0.0075 \\
0.0060 \\
0.0090 \\
0.0090 \\
0.010 \\
0.010 \\
0.011 \\
0.011 \\
0.012 \\
0.0080 \\
0.011 \\
0.0088 \\
0.0083 \\
0.0090 \\
0.0080 \\
\ldots \ldots \ldots . .\end{array}$ & $\begin{array}{l}0.038 \\
0.012 \\
0.025 \\
0.028 \\
0.011 \\
0.011 \\
0.020 \\
0.020 \\
0.020 \\
0.020 \\
0.022 \\
0.030 \\
0.026 \\
0.030 \\
0.030 \\
0.033 \\
0.021 \\
0.026 \\
0.030 \\
0.034 \\
0.027 \\
0.030 \\
\ldots \ldots \ldots .\end{array}$ & $\begin{array}{l}0.022 \\
0.0044 \\
0.0071 \\
0.0067 \\
0.0052 \\
0.0051 \\
0.0067 \\
0.0055 \\
0.0046 \\
0.0062 \\
0.0064 \\
0.0075 \\
0.0072 \\
0.0080 \\
0.0080 \\
0.0088 \\
0.0058 \\
0.0077 \\
0.0068 \\
0.0067 \\
0.0067 \\
0.0063 \\
\ldots \ldots \ldots \ldots\end{array}$ & $\begin{array}{c}2.3 \\
3.3 \\
4.0 \\
5.1 \\
7.8 \\
8.5 \\
9.4 \\
10 \\
11 \\
13 \\
14 \\
16 \\
17 \\
19 \\
20 \\
24 \\
25 \\
27 \\
29 \\
31 \\
34 \\
39 \\
40\end{array}$ & 54 \\
\hline
\end{tabular}

NOTE: All specimens were completely submerged and exposed at the same time in an open vat containing about 265 gal of salt water. Mean solution temp., $73^{\circ} \mathrm{F}$; min, $64{ }^{\circ} \mathrm{F}$; $\max , 81^{\circ} \mathrm{F}$. Area of specimen, $1 / 6 \mathrm{ft}^{2}\left(155 \mathrm{~cm}^{2}\right)$ 


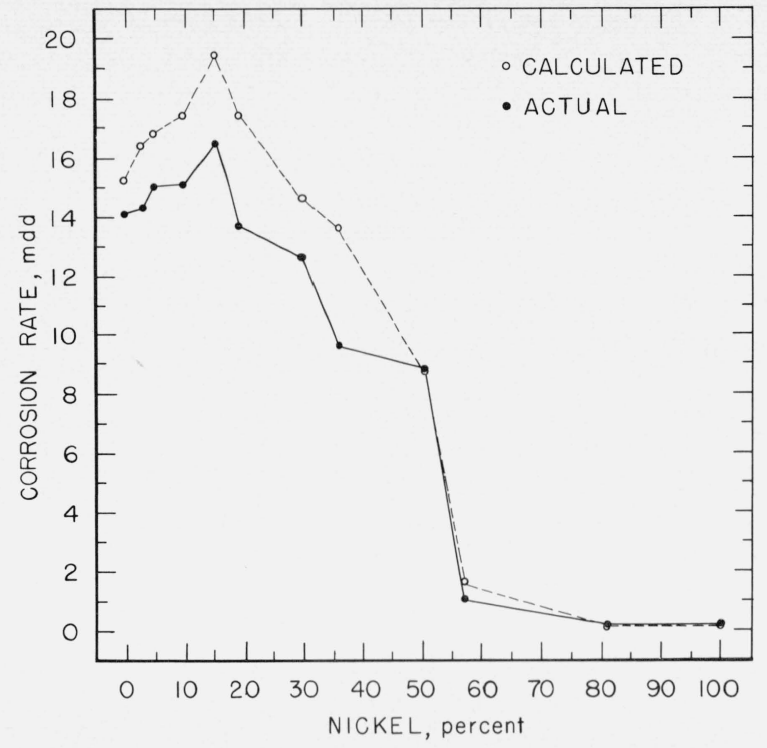

FiguRE 5. Effect of nickel alloyed with iron on the corrosion rates of alloys exposed for 7 months to W ashington, D.C. city water to which was added 3 percent by weight of sodium chloride.

based on the actual weight loss for 210 days.

based on the cumulative weight loss as calculated from the breaks in polarization curves (table 3 ).

day (table 3) after which the corrosion potential changed from $-0.343 \mathrm{~V}$ to $-0.495 \mathrm{~V}$ and the corrosion current increased sevenfold. The corrosion current pertaining to specimen 9 was minimum when its corrosion potential was the least active $(-0.285 \mathrm{~V})$ on the 7 th day of exposure. For a comparison of the corrosion potentials of all alloys on the $202 \mathrm{~d}$ day of exposure, see figure 4 (at zero current). Perhaps, the still water surrounding the specimens, where a greater chance for oxygen depletion occurred, may have prevented a continuation of the film-forming tendencies initially exhibited by the 36 and $50 \mathrm{Ni}$ alloys. In moving water, the oxide films would probably have been more stable and might have prevailed.

The relationship between the two corrosion rate measuring techniques is shown in figure 6 . The line through the points is drawn with a slope of -1 , the theoretical basis for which was given by Stern [4]. The values of $\Delta V \mid \Delta I$ are based on the change in potential caused by the increase of applied current from zero to a value slightly larger than the current $I_{p}$, as indicated by arrows in figure 3 when the corrosion current is zero or negligible as indicated by the increase polarization rate. Selecting values of applied current smaller than $I_{p}$ could result in erroneous values of $\Delta V$ because the changes in potential might be too small for reliable measurement. Once a relationship, as in figure 6 , is established for a given environment, corrosion rates can be approximated simply by measuring $\Delta V \mid \Delta I$.

As the corrosion currents were controlled by the cathodic reactions, almost without exception (table 3 ), the values $\Delta V / \Delta I$ were calculated from the cathodic polarization curves. The relationship between the

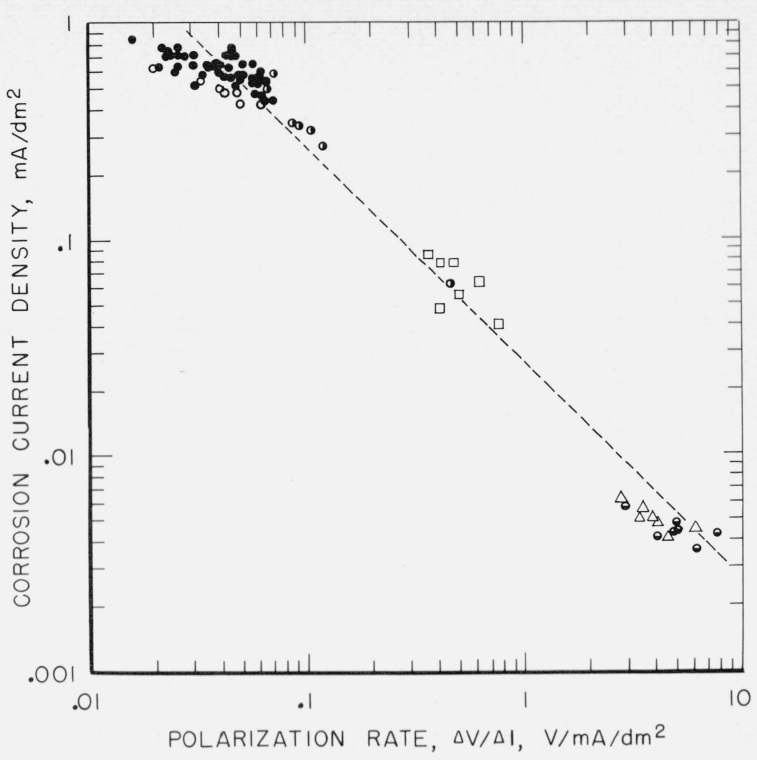

FiguRE 6. Logarithmic relationship between the corrosion current density, calculated from breaks in cathodic and anodic polarization curves, and the controlling polarization rate (cathodic) of nickel, iron, and binary alloys of nickel and iron.

Sublegend: Seven values are shown for each specimen based on measurements made at periodic intervals during the 210-day exposure period.

$\begin{array}{lr}- \text { Specimens } 1 \text { through } 7,0-30 \mathrm{Ni} . \\ \text { Specimen 8, } & 36 \mathrm{Ni} . \\ \text { Specimen 9, } & 50 \mathrm{Ni} . \\ \square \text { Specimen 10, } & 57 \mathrm{Ni} . \\ \triangle \text { Specimen 11, } & 81 \mathrm{Ni} . \\ - \text { Specimen 12, } & 100 \mathrm{Ni} .\end{array}$

polarization rates $\Delta V / \Delta I$ and the actual corrosion rates (weight losses) of the 12 specimens is shown in figure 7 , the line through the points again being drawn with slope of -1 .

\section{Summary}

Ten binary alloys of nickel and iron (series of 3 to $81 \% \mathrm{Ni}$ ) and the metals nickel and iron, 12 specimens in all, were exposed for 210 days to about 265 gals of still Washington, D.C., tap water $\left(64-81^{\circ} \mathrm{F}\right)$ to which was added 3 percent by weight of sodium chloride. Corrosion currents were calculated periodically from breaks in polarization curves, averaged for each of the 22 periods and converted to cumulative weight losses by Faraday's law. The calculated weight losses differed from the actual weight losses (resulting from corrosion) by from 1 to 61 percent, averaging 22 percent for the 12 specimens. The iron lost about 85 times as much weight as did the nickel while the ratio of the respective areas apparently corroded was about 4000 to 1 . Corrosion of the nickel seemed to be confined to one pit about 0.064 in. $(1.6 \mathrm{~mm})$ diam. 


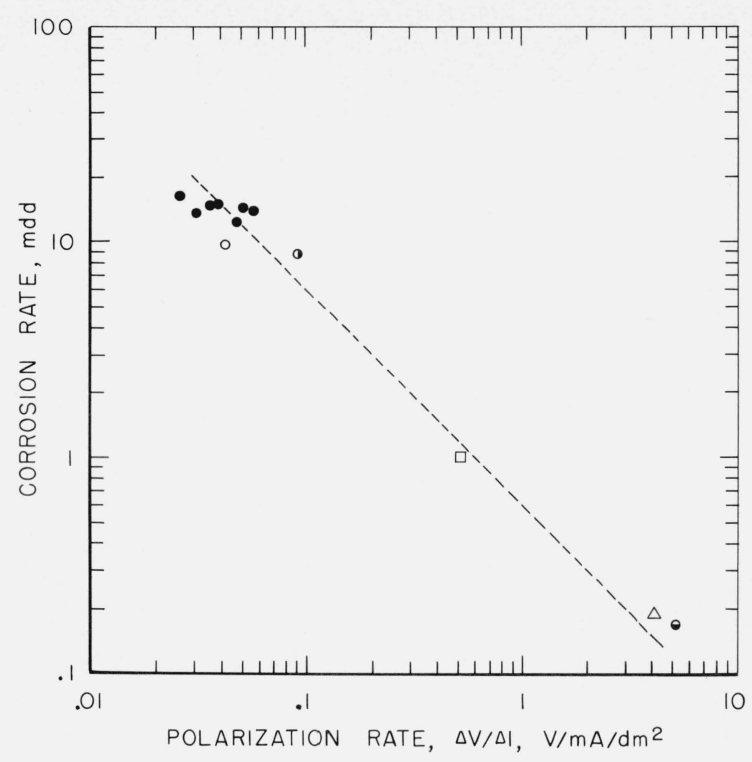

FIGURE 7. Logarithmic relationship between corrosion rate based on actual weight loss and the controlling polarization rate of nickel, iron, and binary alloys of nickel and iron.

Sublegend: Each point pertains to a specimen and the polarization rate is the average of seven measurements made at periodic intervals during the 210-day exposure period.

$\begin{array}{lr}\text { Specimens } 1 \text { through 7, 0-30 Ni. } \\ \text { Specimen 8, } & 36 \mathrm{Ni} \text {. } \\ \text { Specimen 9, } & 50 \mathrm{Ni} . \\ \square \text { Specimen 10, } & 57 \mathrm{Ni} . \\ \triangle \text { Specimen 11, } & 81 \mathrm{Ni} . \\ \odot \text { Specimen 12, } & 100 \mathrm{Ni} .\end{array}$

Polarization rates, $\Delta V \mid \Delta I$, of the 12 specimens, referred to by most investigators as polarization resistance, were plotted on logarithmic coordinates against corrosion current densities calculated from the same curves by the break method and found to fit a curve having the theoretical slope of -1 . Similarly, the actual weight losses of the 12 specimens plotted on logarithmic coordinates versus their average polarization rates also revealed a slope of -1 . Thus, once having established the relationship between corrosion current density (from breaks in polarization curves) and polarization rates, $\Delta V \mid \Delta I$, corrosion current densities can be approximated for other alloys in the particular environment by simply measuring $\Delta V \mid \Delta I$.
The primary purpose of the laboratory work was to evaluate two polarization techniques as methods for measuring rates of corrosion in an aqueous solution. Of secondary interest to the author was the observation that the biggest benefit in corrosion resistance occurred in changing from 50 to 57 percent Ni. Both the calculated and the actual weight losses revealed a reduction in corrosion of over 80 percent for the 57 $\mathrm{Ni}$ alloy over that of the $50 \mathrm{Ni}$ alloy.

The author gratefully acknowledges the cooperation of the personnel of the Research Laboratory, Armco Steel Corporation, Baltimore, Md., who arranged for the fabrication and prepared the alloys.

\section{References}

[1] W. J. Schwerdtfeger, Corrosion rates of ferrous alloys (Fe-Cr and $\mathrm{Fe}-\mathrm{Cr}-\mathrm{Si}$ ) measured by polarization technique, J. Res. NBS 66C (Engr. and Instr.), No. 3, 245 (July-Sept. 1962).

[2] W. J. Schwerdtfeger and O. N. McDorman, Measurement of the corrosion rate of a metal from its polarizing characteristics, J. Electrochem. Soc. 99, 407 (1952).

[3] R. V. Skold and T. E. Larson, Measurement of the instantaneous corrosion rate by means of polarization data, Corrosion 13 , 139t (Feb. 1957).

[4] Milton Stern, A method for determining corrosion rates from linear polarization data, Corrosion 14, 440t (Sept. 1958).

[5] E. H. Phelps, Electrochemical techniques for measurement and interpretation of corrosion, Corrosion 18, 239t (June 1962).

[6] W. J. Schwerdtfeger and R. J. Manuele, Coatings formed on steel by cathodic protection and their evaluation by polarization measurement s, J. Res. NBS 65C (Engr. and Instr.) No. 3, 171 (July-Sept. 1961).

[7] W. J. Schwerdtfeger, A study by polarization techniques of the corrosion rates of aluminum and steel underground for sixteen months, J. Res. NBS 65C (Engr. and Instr.) No. 4, 271 (Oct.-Dec. 1961).

[8] W. J. Schwerdtfeger, Current and potential relations for the cathodic protection of steel in a high resistivity environment, J. Res. NBS 63C (Engr. and Instr.) No. 3, 37 (July-Sept. 1959); Corrosion 16,79 (May 1960).

[9] LaQue and Copson, Corrosion Resistance of Metals and Alloys, J. S. Pettibone, Nickel-Iron Alloys p. 459, ACS monograph Series 158 (Reinhold Publishing Corp., New York, N.Y., 1963).

[10] J. S. Marsh, Alloys of Iron and Nickel, Vol. 1 (McGraw-Hill Book Co., Inc., New York, N.Y., 1938).

(Paper 70C3-230) 